\title{
Penelitian Awal: Faktor Risiko pada Sepsis Neonatorum Awitan Dini
}

\author{
Rosalina D Roeslani, Idham Amir, M. Hafiz Nasrulloh, Suryani \\ Departemen Ilmu Kesehatan Anak RS Cipto Mangunkusumo-Fakultas Kedokteran Universitas Indonesia, \\ Jakarta
}

Latar belakang. Sepsis neonatorum merupakan masalah besar di negara berkembang seperti Indonesia. Selain itu, sepsis menyebabkan kematian serta kesakitan, sukar ditegakkan diagnosis pasti, dan tata laksana yang memerlukan biaya mahal.

Tujuan. Mengetahui faktor risiko pada ibu dan bayi yang berhubungan dengan sepsis neonatorum awitan dini (SNAD).

Metode. Retrospektif kasus kontrol menggunakan analisis bivariat dan multivariat diruang perawatan bayi baru lahir Divisi Perinatologi Departemen Ilmu Kesehatan Anak RSCM Jakarta periode Januari-Juni 2012.Populasi penelitian adalah data rekam medik bayi baru lahir dengan diagnosis SNAD. Besar sampel berdasarkan rule of thumb, sehingga diperlukan 90 sampel dari 9 faktor risiko.

Hasil. Diperoleh 90 kasus sepsis dan 100 kontrol. Satu dari 90 kasus kontrol diperoleh hasil biakan positif bakteri Gram positif. Penelitian menunjukkan 4 faktor yang berhubungan erat dengan terjadinya sepsis berdasarkan analisis bivariat dengan $\mathrm{p}<0,05$, yaitu ketuban pecah lebih dari 24 jam, demam dengan suhu lebih dari $38^{\circ} \mathrm{C}$, usia gestasi $<37$ minggu, dan nilai APGAR rendah. Hasil analisis multivariat didapatkan usia gestasi <37 minggu OR 55,13 (15,98-190,17) dan nilai APGAR rendah OR 4,102 (1,04-16,140) berhubungan erat dengan terjadinya sepsis pada bayi baru lahir.

Kesimpulan. Pada neonatus yang lahir di RSCM Jakarta apabila terdapat faktor risiko prematur (usia gestasi $<37$ minggu), dan atau nilai APGAR rendah maka harus dilakukan skrining sepsis, pemantauan ketat terhadap timbulnya SNAD, bila melakukan tindakan intervensif maka harus dengan tindakan septik-antiseptik yang ideal,serta pemberian antibiotik empiris dapat dipertimbangkan. Sari Pediatri 2013;14(6):363-8.

Kata kunci: sepsis neonatorum, faktor risiko

epsis neonatorum biasa diartikan sebagai gejala sistematik infeksi oleh bakteri, virus, dan jamurpada periode neonatal dengan gejala awal yang bervariasi, dari hanya malas

Alamat korespondensi:

Dr. Rosalina Dewi Roeslani, Sp.A. Divisi Perinatologi Departemen IKA RS Cipto Mangunkusumo - FKUI, Jakarta. E-mail: rosiroeslani@ gmail.com minum, hingga syok septik. ${ }^{1}$ Sepsis neonatorum masih merupakan masalah besar di beberapa Negara, terutama negara berkembang seperti Indonesia. Selain menyebabkan kematian serta kesakitan, sukar ditegakkan diagnosis pasti, dan tata laksana yang memerlukan biaya mahal.

Insiden sepsis neonatorum di dunia berkisar antara 1-8 per 1000 kelahiran hidup. Pada negara 
maju seperti Amerika, kejadian sepsis sejak 1980 bervariasi diantara 2-4 per 1000 kelahiran hidup ${ }^{1,2}$ sedangkan di negara berkembang seperti di India, angka kejadiannya 34-37 per 1000 kelahiran hidup. ${ }^{3}$ Indonesia belum mempunyai data pasti tentang kejadian sepsis.Di Rumah Sakit Cipto Mangunkusumo (RSCM) tahun 2009, insiden sepsis neonatorum adalah 98 per 1000 kelahiranhidup. Angka kejadian yang tinggi karena RSCM adalah senter pelayanan tersier dan pusat rujukan dari hampir seluruh wilayah Indonesia. Kejadian sepsis yang tinggi di RSCM juga menyebabkansebagian besar bayi mendapatkan antibiotik karena gejala klinis dan marker/petanda sepsis menunjukkan adanya infeksi.

Kepustakaan menunjukkan 20-30 dari total bayi sepsis mendapat terapi antibiotik yang tidak diperlukan. ${ }^{1}$ Penggunaan antibiotik yang berlebihan akan meningkatkan resistensi kuman, biaya pengobatan,serta komplikasi yang dapat timbul dari pemberian antibiotik tersebut. Selain itu, sebagian besar bayi sepsis baru yang mendapat terapi setelah terjadi perburukan menyebabkan peningkatan mortalitas, morbiditas, dan mengurangi kemungkinan untuk sembuh total. ${ }^{4}$ Keadaan tersebut menjadi alasan diperlukannya alat untuk membantu dokter dalam deteksi sepsis pada bayi baru lahir (BBL) terutama sepsis awitan dini (SNAD), meliputifaktor-faktor risiko perinatal, gejala klinis yang timbul pertama kali, serta pemeriksaan penunjang.

Sepsis awitan dini merupakan infeksi perinatal yang terjadi segera dalam 48 jam pertama kehidupan, dan biasa disebabkan oleh mikroorganisme yang berasal dari ibu pada saat sebelum(in utero), atau selama proses persalinan. ${ }^{4}$ Sejak tahun 2005, Divisi Perinatologi RSCM telah menggunakan faktor-faktor risiko infeksi sebagai salah satu dasar pemberian antibiotik pada BBL dengan gejala sepsis. Faktor risiko sepsis tersebut diambil dari kepustakaannegaranegara lain, dengan organisme penyebab yang berbeda dengan Indonesia, terutama di RSCM. Di beberapa negara organisme penyebab tersering dari SNAD adalah Streptococcus grup $\beta$ dan Escherichia coli, ${ }^{1-4}$ sementara di RSCM pada tahun 2011 adalah $S$ taphylococcus epidermidis, Serratia sp serta Candida tropicalis, sehingga dalam penelitian ini ingin dilihat apakah faktor risiko tersebut berperan juga sebagai faktor prediksi sepsis di masyarakat Indonesia khususnya BBL di RSCM.

\section{Metode}

Penelitian dilakukan secara observasional retrospektif kasus-kontroldiruang perawatan bayi baru lahir Divisi Perinatologi Departemen Ilmu Kesehatan Anak RSCM periode Januari-Juni 2012.Populasi penelitian adalah data rekam medik bayi baru lahir dengan diagnosis SNAD.

Besar sampel berdasarkanrule of thumb, sehingga diperlukan 90 sampel dari 9 Faktor risiko.

Kriteria inklusi adalah sepsis awitan dini dengan kultur positif, sepsis awitan dini secara klinis menunjukkan gejala sepsis dalam usia 48 jam, dan lahir di RSCM.Kriteria eksklusi adalah lahir di luar RSCM, dan BBL dengan kelainan bawaan.

Dikumpulkan rekam medik bayi baru lahir dengan diagnosis SNAD, baik terbukti secara kultur maupun sepsis dengan gejala klinis. Dilihat faktor risiko infeksi perinatal dan hasil skrining sepsis dari darah bayi yaitu leukosit, trombosit, CRP, dan IT.Datadiolah secara bivariat danmultivariat dengan regresi logistik menggunakan program SPSS 19.

\section{Batasan operasional}

- Korioamnionitis adalahibu demam pada saat intrapartum (suhu $>37,8^{\circ} \mathrm{C}$ ) ditambah lebih dari 2 gejala sebagai berikut fetal takikardia, uterine tenderness, leukositosis pada ibu (leukosit $>15.000)$. $^{5}$

- Perhitungan usia gestasi berdasarkan ballard.

- Provensepsis terisolasinya organisme dari tempat yang normalnya steril (darah, cairan serebrospinal, dan urin) yang berhubungan dengan keadaansepsis. ${ }^{6}$

- Clinical sepsis adalah suatu episode dengan hasil kultur negatif, tetapi ditemukan keadaan sebagai berikut; gejala-gejala klinis sepsis; terisolasinya bakteri dari saluran genital ibu, plasenta, dan atau atau cairan lambung BBL; terisolasinya bakteri dari trakea yang berhubungan dengan perubahan gambaran pencitraan dada yang konsisten dengan pneumonia; IT Rasio >0,2 danCRP kuantitatif $>10 \mathrm{mg} / \mathrm{L}$; dan terapi antibiotik yang tepat selama lebih dari 3 hari.

Faktor risiko perinatal,, 56 yaitu prematur /neonatus kurang bulan (NKB, <37 minggu), bayi berat lahir rendah (BBLR), ibu demam intrapartum $\left(\right.$ suhu $\left.>38^{\circ} \mathrm{C}\right)$, 
ketuban pecah dini (KPD, >18 jam), korioamnionitis, hipoksia intrapartum (apgar skor), infeksi saluran kencing (ISK) pada ibu, dan keputihan pada ibu yang tidak diobati

\section{Hasil}

Terdapat perbedaan bermakna antara kelompok sepsis dan kelompok nonsepsis berdasarkan usia gestasi dan berat lahirseperti tertera padaTabel 1 .

Tabel 1. Karakteristik sampel

\begin{tabular}{lcc}
\hline Variabel & $\begin{array}{c}\text { Sepsis } \\
\mathrm{n}=90\end{array}$ & $\begin{array}{c}\text { Non sepsis } \\
\mathrm{n}=100\end{array}$ \\
\hline Usia gestasi (minggu) & $33,75 \pm 3,66$ & $38,00 \pm 1,35$ \\
Berat lahir (gram) & $1945 \pm 811$ & $2993 \pm 448.7$ \\
Jenis kelamin & & \\
$\quad$ Laki - laki & 50 & 44 \\
$\quad$ Perempuan & 40 & 56 \\
Jenis persalinan (n) & & \\
$\quad$ Sectio caesarea & 61 & 70 \\
$\quad$ Per vaginam & 29 & 30 \\
\hline
\end{tabular}

Tabel 2. Profil laboratorium kelompok sepsis pada pemeriksaan pertama

\begin{tabular}{lc}
\hline Variabel laboratorium & Rerata \pm SD \\
\hline Hemoglobin & $15,29 \pm 2,72$ \\
Hematokrit & $45,75 \pm 8,06$ \\
Leukosit & $11,768 \pm 6,083$ \\
Trombosit & $190,830 \pm 92,541$ \\
CRP & $6,91 \pm 17,58$ \\
IT ratio & $0,52 \pm 2,22$ \\
\hline
\end{tabular}

Gejala yang sering timbul sehingga bayi baru lahir memerlukan rawatan inap, dan terapi sepsis adalah sesak $(64,4 \%)$, letargis $(42,2 \%)$, hipotermia $(37,8 \%)$, muntah $(16,7 \%)$, dan perdarahan saluran cerna $(14,4 \%)$ (Gambar 1).

Bayi baru lahir di RSCM yang mempunyai faktor risiko sepsis, dilakukan skrining tes, terdiri dari darah perifer lengkap ( $\mathrm{Hb}, \mathrm{Ht}$, leukosit, trombosit), dan $C$ reactive protein (CRP)(Tabel 2$)$. Pemeriksaan

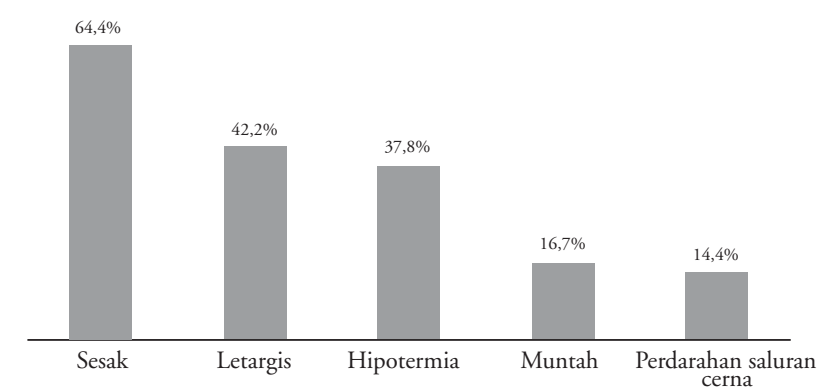

Gambar 1. Gejala awitan dini yang sering terjadi pada kelompok sepsis

kultur akan ditambahkan pada bayi baru lahir yang menunjukkan gejala sepsis. Hasil kultur positif didapatkan 1 dari 90 dengan hasil Streptococcus haemolyticus grup $D$.

Tabel 3 menunjukkan 4 faktor yang berhubungan erat dengan terjadinya sepsis berdasarkan analisis bivariat dengan $\mathrm{p}<0,05$, yaitu ketuban pecah lebih dari $24 \mathrm{jam}$, demam dengan suhu lebih dari $38^{\circ} \mathrm{C}$, usia gestasi <37 minggu, dan nilai APGAR rendah. Hasil analisis dilanjutkan dengan analisismultivariat yang menghasilkan bahwa usia gestasi $<37$ minggu dan nilai APGAR rendah berhubungan erat dengan terjadinya sepsis pada bayi baru lahir (Tabel 4).

Tabel 4. Hasil analisis multivariat

\begin{tabular}{lcccc}
\hline Variabel & $\mathrm{B}$ & $\mathrm{p}$ & Rasio Odd & Confident interval \\
\hline ISK & 0,319 & 0,525 & 1.376 & $0,51-3,69$ \\
Ketuban pecah & 0,397 & 0,518 & 1.488 & $0,45-4,96$ \\
Kembar & 0,606 & 0,441 & 1.832 & $0,39-8,56$ \\
Jenis kelamin & 0,583 & 0,157 & 1.791 & $0,79-4,01$ \\
Demam in partu & 2.141 & 0,072 & 8.511 & $0,82-87,8$ \\
APGAR rendah & 1.411 & 0,043 & 4.102 & $1,04-16,14$ \\
Usia gestasi & 4.010 & 0,000 & 55.133 & $15,98-190,17$ \\
Constanta & -1.278 & 0,000 & .279 & \\
\hline
\end{tabular}


Tabel 3. Hasil analisis bivariat

\begin{tabular}{|c|c|c|c|c|c|c|c|c|}
\hline & \multicolumn{6}{|c|}{ Kelompok } & \multirow{3}{*}{$\mathrm{p}$} & \multirow{3}{*}{ OR } \\
\hline & \multicolumn{2}{|c|}{ Sepsis } & \multicolumn{2}{|c|}{ Kontrol } & \multicolumn{2}{|c|}{ Total } & & \\
\hline & $\mathrm{n}$ & $\%$ & $\mathrm{n}$ & $\%$ & $\mathrm{n}$ & $\%$ & & \\
\hline \multicolumn{9}{|l|}{ Jenis kelamin } \\
\hline Laki-laki & 52 & 57,8 & 44 & 44,0 & 96 & 50,5 & 0,058 & $1,74(0,94-3,23)$ \\
\hline Perempuan & 38 & 42,2 & 56 & 56,0 & 94 & 49,5 & & \\
\hline \multicolumn{9}{|l|}{ Gejala mayor } \\
\hline \multicolumn{9}{|c|}{ Ketuban berbau } \\
\hline $\mathrm{Ya}$ & 1 & 1,1 & 1 & 1,0 & 2 & 1,1 & 0,940 & $1,11(0,01-41,36)$ \\
\hline Tidak & 89 & 98,9 & 99 & 99,0 & 188 & 98,9 & & \\
\hline \multicolumn{9}{|c|}{ Ketuban pecah $>24 \mathrm{Jam}$} \\
\hline $\mathrm{Ya}$ & 22 & 24,4 & 9 & 9,0 & 31 & 16,3 & 0,004 & $3,27(1,33-8,24)$ \\
\hline Tidak & 68 & 75,6 & 91 & 91,0 & 159 & 83,7 & & \\
\hline \multicolumn{9}{|c|}{ Demam in partu $>380 \mathrm{C}$} \\
\hline $\mathrm{Ya}$ & 6 & 6,7 & 1 & 1,0 & 7 & 3,7 & 0,038 & $7,07(0,82-158,99)$ \\
\hline Tidak & 84 & 93,3 & 99 & 99,0 & 183 & 96,3 & & \\
\hline \multicolumn{9}{|l|}{ Gejala minor } \\
\hline \multicolumn{9}{|c|}{ Kehamilan ganda } \\
\hline $\mathrm{Ya}$ & 10 & 11,1 & 5 & 5,0 & 15 & 7,9 & 0,119 & $2,38(0,71-8,37)$ \\
\hline Tidak & 80 & 88,9 & 95 & 95,0 & 175 & 92,1 & & \\
\hline \multicolumn{9}{|c|}{ Usia gestasi $<37$ minggu } \\
\hline Ya & 57 & 63,3 & 3 & 3,0 & 60 & 31,6 & 0,001 & $55,85(15,38-240,27)$ \\
\hline Tidak & 33 & 36,7 & 97 & 97,0 & 130 & 68,4 & & \\
\hline \multicolumn{9}{|c|}{ Ketuban pecah > $12 \mathrm{Jam}$} \\
\hline $\mathrm{Ya}$ & 5 & 5,6 & 10 & 10,0 & 15 & 7,9 & 0,257 & $0,53(0,15-1,78)$ \\
\hline Tidak & 85 & 94,4 & 90 & 90,0 & 175 & 92,1 & & \\
\hline \multicolumn{9}{|c|}{ Keputihan ya } \\
\hline Ya & 15 & 16,7 & 14 & 14,0 & 29 & 15,3 & 0,610 & $1.23(0,52-2,91)$ \\
\hline Tidak & 75 & 83,3 & 86 & 86,0 & 161 & 84,7 & & \\
\hline \multicolumn{9}{|c|}{ ISK atau tersangka ISK tidak diobati } \\
\hline Ya & 25 & 27,8 & 17 & 17,0 & 42 & 22,1 & 0,074 & $1.88(0,89-4,00)$ \\
\hline Tidak & 65 & 72,2 & 83 & 83,0 & 148 & 77,9 & & \\
\hline \multicolumn{9}{|l|}{ Apgar rendah } \\
\hline $\mathrm{Ya}$ & 17 & 18,9 & 4 & 4,0 & 21 & 11,1 & 0,001 & $5,59(1,67-20,60)$ \\
\hline Tidak & 73 & 81,1 & 96 & 96,0 & 169 & 88,9 & & \\
\hline
\end{tabular}

\section{Pembahasan}

Perbedaan signifikan antara kelompok sepsis dan non sepsis penelitian kami adalah usia gestasi $(33,76$ vs 38,00 minggu)) dan berat lahir (1945 vs 2993 gram), keadaan tersebut karena RSCM adalah rumah sakit rujukan tersier sehingga bayi berisiko tinggi salah satunya neonatus kurang bulan (NKB) banyak di lahirkan di RS ini. Insiden kelahiran NKB ini kurang lebih $25 \%$ - $30 \%$ dan merupakan $\pm 60 \%$ dari jumlah bayi yang dirawat inap di Divisi Neonatologi Departemen Ilmu Kesehatan Anak RSCM.

Gejala yang membuat bayi baru lahir dirawat dengan tersangka sepsis adalah sesak napas, letargis, hipotermia, dan gejala di saluran cerna seperti muntah serta perdarahan saluran cerna. Pada beberapa kepustakaan ${ }^{7,8}$ sesak napas merupakan gejala tersering timbul dan penelitian oleh Chacko serta Inderpreet ${ }^{2}$ di India Utara, 65 bayi baru lahir dari 1743 bayi lahir hidup menderita sepsis dengangejala pneumonia 
sebesar 66\%.Pada penelitian kami, gejala sesak napas yang timbul karena penyakit membran hyalin $(\mathrm{PMH})$, atau pneumonia.

Penyakit membrane hyaline kemungkinan lebih banyak terjadi di penelitian kami karena karakteristik sampel sebagian besar adalah neonatus kurang bulan (NKB), yaitu 57 NKB dari 90 sampel neonatus. Skrining laboratorium untuk menjaring sepsis pada neonatus adalah darah perifer lengkap (hemoglobin, leukosit, trombosit, hematokrit) serta petanda sepsis seperti CRP dan IT. Penelitian kami menunjukkan hasil darah perifer dalam batas normal sedangkan CRP sebesar 6,91 $\pm 17,58$ dan IT rasio 0,52 $\pm 2,22$. Penelitian oleh Kocabas $\mathrm{dkk}^{9}$ melaporkan bahwa kadar minimum CRP yang menunjukkan adanya infeksi adalah $10 \mathrm{mg} \%$ dengan kadar pada saat pertama skrining adalah $16 \mathrm{mg} \%$. Penelitian lain menggunakan kadar yang berbeda untuk CRP, seperti Shah ${ }^{10}$ dengan CRP $>6 \mathrm{mg} / \mathrm{dl}$, dan Resch ${ }^{11} \mathrm{CRP}>8 \mathrm{mg} / \mathrm{L}$. Penelitian kami dapat menjadi pertimbangan untuk menurunkan cut of ponit dari CRP di divisi kami, selama ini, kadar yang di gunakan adalah CRP $>10 \mathrm{mg} / \mathrm{dl}$. Petanda sepsis lain yang digunakan dipenelitian kami adalah IT rasio yang menunjukkan telah terjadi peningkatan sebesar 0,52 dengan batasan yang digunakan adalah IT rasio $>0.2$ sesuai dengan penelitian Resch dkk.

Hasil kultur positif pada 1 bayi adalah Streptococcus haemolyticus grup $D$, berbeda dengan laporan kuman penyebab sebelumnya di RSCM pada tahun 20072012 yang sebagian besar adalah bakteri Gram negatif seperti Acinetobacter sp, Enterobacter sp, Seratia sp, Pseudomonas, dan lain-lain. ${ }^{12}$ Pada dua tahun terakhir, Divisi Neonatologi RSCM terjadi peningkatan hasil kultur oleh bakteri Gram positif walaupun masih di dominasi oleh bakteri Gram negatif, yaitu ditemukan kuman golongan Staphylococcus pada tahun 2011 sebesar $11,11 \%$ dari seluruh hasil kultur. Peningkatan infeksi kuman Gram positif mungkin karena teknik septik antiseptik yang lebih baikdi ruang operasi dan bersalin departemen Kebidanan FKUI-RSCM dan penggunaan antibiotik pada ibu hamil dengan tersangka sepsis yang sesuai dengan hasil kultur.

Pada penelitian kami, faktor yang berhubungan erat dengan terjadinya sepsis berdasarkan analisis bivariat dengan $\mathrm{p}<0,05$, yaitu ketuban pecah lebih dari $24 \mathrm{jam}$, demam dengan suhu lebih dari $38^{\circ} \mathrm{C}$, usia gestasi(UG)<37 minggu, dan nilai APGAR rendah. Hasil analisis dilanjutkan dengan analisis multivariat yang memberikan hasil bahwa usia gestasi $<37$ minggu dan nilai APGAR rendah berhubungan erat dengan terjadinya sepsis pada bayi baru lahir.

Di negara berkembang seperti India dan $\mathrm{Nepal},{ }^{2,10,13}$ beberapa penelitian mempunyai faktor risiko yang sama seperti penelitian kami, yaitu nilai APGAR yang rendah dan $U G<37$ minggu atau prematur/NKB. Pelayanan kesehatan yang belum baik terutama untuk ibu melahirkan dan neonatus meyebabkan nilai APGAR yang rendah. Hubungan erat antara nilai APGAR rendah dan infeksi dapat disebabkan karena prosedur intervensi yang tinggi pada bayi tersebut sejak usia awal sehingga dapat saja terinfeksi oleh kuman di kamar bersalin seperti hipotesis yang di laporkan oleh Shah dkk. ${ }^{10}$ Sedangkan hubungan yang erat antara terjadinya sepsis dan neonatus kurang bulan atau prematur karena adanya defisiensi imunitas yang relatif. ${ }^{10}$ Di Divisi Perinatologi, neonatus irawat inap sebagian besar $( \pm 60 \%)$ adalah prematur, dan karakteristik penelitian kami mendapatkan 57/90 kasus sepsis adalah prematur. Kelahiran prematur belum dapat dicegah, baik di negara maju maupun berkembang. Infeksi adalah sebagian besar penyebab kelahiran prematur di negara berkembang seperti di Indonesia.

Pada analisis bivariat ketuban pecah $>24 \mathrm{jam}$, dan demam pada ibu dengan suhu $>38^{\circ} \mathrm{C}$ ditunjukkan hubungan yang erat dengan berkembangnya sepsis, tetapi tidak terbukti pada analisis multivariat. Hasil tersebut menunjukkan bahwa keduanya merupakan faktor yang memperkuat kejadian sepsis yang tinggi pada bayi lahir prematur dan asfiksia (nilai APGAR rendah).

\section{Kesimpulan}

Penelitian kami menunjukkan bahwa usia gestasi $<37$ minggu dan nilai APGAR rendah merupakan faktor risiko independen berdasarkan analisis multivariat terhadap terjadinya sepsis neonatorum awitan dini. Pada neonatus yang lahir di RSCM, bila terdapat faktor risiko prematur (usia gestasi $<37$ minggu) dan/ atau nilai APGAR yang rendah maka harus dilakukan skrining sepsis, pemantauan ketat terhadap timbulnya SNAD, bila melakukan tindakan intervensif maka harus dengan tindakan septik-antiseptik yang ideal dan pemberian antibiotik empiris dapat dipertimbangkan. Keterbatasan penelitian kami adalah sampel sepsis lebih berdasarkan klinis dan laboratorium (clinicalsepsis) dan hanya 1 dari 90 neonatus yang terbukti berdasarkan 
kultur.Diperlukan penelitian lebih lanjut dengan menggunakan sampel sepsis berdasarkan hasil kutur positif Proven Sepsis) sehingga didapatkan faktor risiko maternal maupun neonatus yang lebih kuat.

\section{Daftar pustaka}

1. Baltimore R S. Neonatal Sepsis : Epidemiology and management. Pediatr Drugs 2003;5:723-40.

2. Chacko B, Sohi I. Early onset neonatal sepsis. Indian J Pediatr 2005;72:23-6.

3. Ananthakrishnan D, Gunasekaran D. Etiology and risk faktors for early neonatal sepsis. Indian J Medical Microbiol2009;27:279.

4. Griffin M P, O'Shea T M, Bissonette E A, Harrell Jr F E, Lake D E dan Moorman J R. Abnormal heart rate characteristic preceding neonatal sepsis and sepsis-like illness. Pediatric Research2003;53:920-6.

5. Yancey M, Duff P, KubilisP, Clark P, Frentzen B. Risk faktors for neonatal sepsis. The American College of Obstetricians and Gynecologists 1996;82:188-94.

6. The royal women's hospital victoria. The royal women's hospital neonatal services : clinician's handbook;2009.

7. Ferrieri P, Wallen LD. Neonatal bacterial sepsis. Dalam: Gleason C, Devaskar S, penyunting. Avery's diseases of the newborn.Edisi 9. Philadelphia:Elsevier Saunders; 2012. h. 538-50.

8. Puopolo KM. Bacterial and fungal infections. Dalam: John P. Cloherly, Eric C E, Anne R H, Ann R. S, penyunting. A Lippincott Manual of Neonatal Care. Edisi ke-7. Philadelphia:Lippincott Williams \& Wilkins;2012. h.624-47.

9. Kocabas E, Sarikçioglu A, Aksaray N, Seydaoglu G, Seyhun Y, Yaman A. Role of procalcitonin, C-reactive protein, interleukin-6, interleukin-8 and tumor necrosis faktoralpha in the diagnosis of neonatal sepsis. Turk J Ped 2007;49:7-20.

10. Shah GS, Budhathoki S, Das BK, Mandal RN. Risk faktors in early neonatal sepsis. Kathmandu Univ Med J2006;4:187-91.

11. Resch B, neubauer K,Hofer N, Resch E, Haas J, Muller W. Episodes of hypocarbia and early onset sepsis are risk faktors for cystic periventricular leukomalacia in the preterm infant. Early Human Development 2012:88;2731.

12. Divisi Perinatologi Departemen Ilmu Kesehatan Anak RSCM. Laporan fetomaternal tahun 2007-2012. RSCM-FKUI.

13. N.B. Mathur, A. Singh, V.K. Sharma, L. Satyanarayana. Evaluation of risk faktors for fatal neonatal sepsis. Indian Pediatr 1996;33:817-22. 